\title{
Detection of Trypanosoma vivax in tissues of experimentally infected goats: what is the role of adipose tissue in the life cycle of this protozoon?
}

\author{
Detecção de Trypanosoma vivax em tecidos de caprinos experimentalmente \\ infectados: qual é o papel do tecido adiposo no ciclo de vida desse \\ protozoário?
}

Rosangela Zacarias Machado1* (D); Kayo José Garcia de Almeida Castilho Neto'; Luiz Ricardo Gonçalves'; Gisele Fabrino Machado²; Maria Cecília Rui Luvizotto²; Rosemeri de Oliveira Vasconcelos; Giulia Jussiani²; Thiago Merighi Vieira da Silva'; Lindsay Unno Gimenes; Andrew Jackson³; Gavin Wright4; Marta Maria Geraldes Teixeira ${ }^{5}$

\author{
'Departamento de Patologia, Reprodução e Saúde Única, Faculdade de Ciências Agrárias e Veterinárias - FCAV, Universidade Estadual \\ Paulista - UNESP, Jaboticabal, SP, Brasil \\ 2Departamento de Clínica, Cirurgia e Reprodução Animal, Faculdade de Medicina Veterinária - FMVA, Universidade Estadual Paulista - \\ UNESP, Araçatuba, SP, Brasil \\ ${ }^{3}$ Department of Infection Biology, University of Liverpool, Liverpool, United Kingdom \\ ${ }^{4}$ Department of Biology, Hull York Medical School, University of York, Wentworth Way, York, United Kingdom \\ Departamento de Parasitologia, Instituto de Ciências Biomédicas - ICB, Universidade de São Paulo - USP, São Paulo, SP, Brasil
}

How to cite: Machado RZ, Castilho Neto KJGA, Gonçalves LR, Machado GF, Luvizotto MCR, Vasconcelos RO et al. Detection of Trypanosoma vivax in tissues of experimentally infected goats: what is the role of adipose tissue in the life cycle of this protozoon? Braz J Vet Parasito/ 2021; 30(4): e017721. https://doi.org/10.1590/S1984-29612021092

\begin{abstract}
Trypanosomiasis, caused by Trypanosoma vivax, is responsible for great economic losses among livestock in Africa and South America. During the life cycle of these parasites, they may present different morphological, metabolic and physiological characteristics depending on the interactions that are encountered at each point of their life cycle. Although T. vivax is frequently reported in the circulation of its mammalian hosts, it has the ability to migrate to the tissues of these individuals. However, this characteristic is poorly understood. In this context, we aimed to investigate the presence of $T$. vivax and the changes caused in different tissues of experimentally infected goats. Despite the animals were not perfused before tissues collection, using different approaches, we demonstrated its presence in different samples, including in the adipose tissue and skin of infected animals. In addition, a mononuclear inflammatory reaction, mostly characterized by an infiltrate of lymphocytes, plasma cells and macrophages were observed. The results highlight the possibility that, like other trypanosomatids, T. vivax may use these tissues during its life cycle. Future studies aiming to elucidate the length of time for which $T$. vivax remains active in these sites, and whether it uses these sites as a refuge from trypanocidal drugs, and whether it is capable of recolonizing the blood circulation, are much needed.
\end{abstract}

Keywords: LAMP, livestock, refuge, trypanosomiasis, Trypanosoma vivax.

\section{Resumo}

A tripanossomíase, causada por Trypanosoma vivax, é responsável por grandes perdas econômicas na bovinocultura da África e da América do Sul. Durante seu ciclo de vida, o parasita pode apresentar diferentes características morfológicas, metabólicas e fisiológicas em função das interações que ele encontra em cada ponto do seu ciclo. Embora o T. vivax seja reportado, frequentemente, na circulação dos seus hospedeiros mamíferos, o protozoário tem a capacidade de migrar para os tecidos desses indivíduos. Entretanto, essa característica é pobremente

Received October 04, 2021. Accepted November 16, 2021.

*Corresponding author: Rosangela Zacarias Machado. E-mail: rzacariasmachado@gmail.com 
conhecida. Neste contexto, o objetivo foi verificar a presença, assim como as alterações causadas pelo T. vivax nos diferentes tecidos de caprinos experimentalmente infectados. Apesar dos animais não terem sido perfundidos antes da coleta dos tecidos, utilizando-se diferentes abordagens, foi evidenciada a presença do T. vivax em diferentes amostras teciduais, incluindo no tecido adiposo e pele dos animais infectados. Além disso, foi observada reação inflamatória mononuclear, caracterizada majoritariamente por infiltrado de linfócitos, plasmócitos e macrófagos. Os resultados evidenciam a possibilidade de que, assim como outros tripanossomatídeos, $T$. vivax pode usar esses tecidos durante o seu ciclo de vida. São necessários futuros estudos, objetivando elucidar o período em que o T. vivax permanece ativo nesses sítios, se ele utiliza esses locais como refúgio das drogas tripanocidas, e se ele é capaz de recolonizar a circulação sanguínea.

Palavras-chave: LAMP, pecuária, refúgio, tripanossomíase, Trypanosoma vivax.

\section{Introduction}

Trypanosomiasis is a cosmopolitan disease that affects humans, domestic animals and wild animals. Trypanosoma vivax, T. evansi, T. equiperdum, T. cruzi and T. theileri are found in animals in South America (Hoare, 1972; Gardiner et al., 1989), and T. vivax is responsible for major economic losses in cattle-rearing in Africa, Asia, Central America and South America (Dávila \& Silva, 2000; Osório et al., 2008).

In the African continent, in areas where Glossina spp. (tsetse) is present, T. vivax is transmitted cyclically, developing in the digestive tract of the fly. In the Americas, where this fly is not present, transmission is performed mechanically by tabanids (horseflies), Stomoxys calcitrans (stable fly) and Haematobia irritans (Serra-Freire \& Rezende, 1988; Cadioli et al., 2012), or iatrogenically by means of fomites (Silva et al., 1996; Cadioli et al., 2012). Transplacental infections have also been described (Silva et al., 2013).

In Brazil, T. vivax infections in ruminant herds have been occurring with increasing frequency. Over the last two decades, outbreaks have been observed in different Brazilian states (Bastos et al., 2020), causing a major economic impact on Brazilian cattle-rearing (Seidl et al., 1999; Jones \& Dávila, 2001).

The clinical signs triggered by the parasite are not very specific, which makes diagnosis difficult. During the course of trypanosomiasis, there are fluctuations in parasitemia or even intervals of undetectable parasitaemia (Almeida et al., 2012; Fidelis et al., 2016). These fluctuations are related to the host's immune response and the antigenic variation of surface variant glycoproteins of trypanosomes (Nantulya, 1990; Stijlemans et al., 2010). In lowparasitemia phases, detection of T. vivax becomes even more challenging (Rebeski et al., 1999; Waal, 2012). Thus, diagnoses based on immunological response (ELISA), molecular tests (PCR and LAMP) and histopathological analyses, contribute greatly to higher-precision diagnosis, thus avoiding maintenance of false-negative animals in the herd and contributing to greater disease control.

In animals that are experimentally and/or naturally infected by $T$. vivax, different anatomopathological findings and histological alterations have been reported in very distinct tissue types (Batista et al., 2006, 2007; Almeida et al., 2010).

So far, no studies have demonstrated any presence of $T$. vivax in the adipose tissue or skin of its vertebrate hosts. However, recent research on T. brucei (which causes human African trypanosomiasis, i.e. sleeping sickness) showed, using a mouse model, that adipose tissue constituted a third major reservoir for this parasite (Trindade et al., 2016). Moreover, Capewell et al. (2016) showed conclusive evidence from a mouse model that T. b. brucei (animal trypanosomiasis) could invade the extracellular tissue of the skin, including but not restricted to the adipose tissue. The same authors also showed the presence of trypanosomes within the skin of undiagnosed humans (Capewell et al., 2016).

Although T. vivax (like T. congolense) is considered to be a species confined to the host's vascular system, some strains in late infections may reach extravascular sites (e.g. lymph nodes, eyes and cerebrospinal fluid). This can cause tissue lesions that are less accessible for drug treatment (Whitelaw et al., 1988; Osório et al., 2008; D'Archivio et al., 2013).

Furthermore, it is extremely important to have knowledge of how trypanocidal drugs used for therapeutic and preventive purposes remain in the circulation (Giordani et al., 2016) and whether or not they enter different tissue types. These characteristics may determine whether or not trypanocidal drugs are effective for controlling trypanosomiasis. Thus, detecting positive animals in a herd, and finding out whether, at some point during the course of infection, $T$. vivax lodges in tissues, is vital for controlling this disease. 
The aim of the present study was to investigate the presence of $T$. vivax and evaluate the histopathological alterations in different tissues of experimentally infected goats.

\section{Animals, Experimental Period and Collection of Material}

Six male goats (Saanen breed) aged four to six months were used. Thirty days before the experimental period, all the animals were wormed (albendazole $7.5 \mathrm{mg} / \mathrm{kg}$, orally). Also, before starting the experiment, the following tests were used to ensure that the animals were not naturally infected: blood smears to investigate hemoparasites; PCR and LAMP to detect T. vivax DNA (Cortez et al., 2009; Njiru et al., 2011); and IFAT (Sampaio et al., 2015) and ELISA (Machado et al., 1997) to detect anti-T. vivax IgG.

Initially, the Miranda isolate of $T$. vivax cryopreserved in liquid nitrogen was thawed and used to infect a goat. The goat was monitored and during the parasitemia peak, the blood sample was collected in tubes containing EDTA. Thereafter, the number of trypomastigote forms was assessed (Brener, 1961) and the animals inoculated. Five animals, after a period of acclimatization (30 days), were inoculated with $1.0 \times 10^{3}$ trypomastigote forms of $T$. vivax (Miranda isolate) intravenously, through the external jugular vein. Similarly, the control animal was inoculated with physiological saline solution. Before (in the acclimatization period) and during the experimental period, the goats were subjected to daily physical examinations, with evaluations of heart and respiratory rates, mucosal staining, skin turgor, lymph node changes and body condition. In addition, blood samples were obtained for laboratory tests (Brener, 1961) in order to ascertain the presence of the parasite.

The animals were euthanized 40 days after infection (DAl), using a combination of xylazine $(0.2 \mathrm{mg} / \mathrm{kg})$ and ketamine $(2 \mathrm{mg} / \mathrm{kg})$, followed by intrathecal injection of lidocaine $(40 \mathrm{ml})$. During the necropsies on the animals, fragments of the following organs/tissues were collected: testicle, skin, liver, spleen, lymph nodes, peritesticular adipose tissue and perirenal adipose tissue.

This research project was approved by the Ethics Committee for Animal Use (CEUA) of the School of Agrarian and Veterinary Sciences, UNESP, Jaboticabal campus, under protocol number 001494/18. The animals were euthanized in accordance with CFMV resolution no. 1000 of May 11, 2012, and this procedure was also approved by the CEUA of FCAV/UNESP.

\section{Histopathology}

Organ/tissue fragments were collected for light microscopy analysis. These were fixed in $10 \%$ formalin solution and buffered with phosphates $(0.15$ molar; $\mathrm{pH} 7.2)$. After 24 hours of fixing, the samples were removed from the formalin solution and placed in $70 \%$ alcohol. They were then dehydrated in solutions of decreasing alcohol concentration, diaphanized in xylol and embedded in paraffin, in accordance with the routine histological technique. Sections of thickness $5 \mu \mathrm{m}$ were cut and stained with hematoxylin and eosin (HE), and these were then used to identify the main morphological alterations. Unstained sections were used for the Immunofluorescence technique.

\section{Indirect Immunofluorescence Reaction on Histological Sections}

The sections of the fragments from the spleen, liver, lymph node, testicle, skin and fat were subjected to the immunofluorescence test. Initially, antigen recovery was performed in a steaming pan (at $100^{\circ} \mathrm{C}$ ), in Envision Target Retrieval Solution High pH buffer (Dako, K8004) for 20 minutes. Nonspecific blockade was implemented using a protein block (Abcam, ab64226) for 30 minutes.

Immune serum samples obtained from cattle (40 th DAl) that had been experimentally infected by $T$. vivax were used as the primary antibody. Serum from uninfected cattle was used as the negative control. The serum samples were diluted in PBS in the proportions of 1:40 and were applied to the sections and incubated at $37^{\circ} \mathrm{C}$ for 30 minutes. Subsequently, the sections were incubated with bovine anti-IgG conjugated with fluorescein isocyanate (Sigma, St. Louis, USA) diluted in PBS and Evans Blue, at $37^{\circ} \mathrm{C}$ for 30 minutes. Lastly, coverslips were mounted on the slides, with addition of buffered glycerin, for viewing under a fluorescence microscope (Olympus, BX-FLA). 


\section{DNA Extraction and Quality}

DNA was extracted from $25 \mathrm{mg}$ of each goat tissue sample (except for the spleen tissue, for which only $10 \mathrm{mg}$ was used), using the DNeasy ${ }^{\circledR}$ Blood \& Tissue kit (Qiagen ${ }^{\circledR}$, Valencia, California, USA), following the manufacturer's recommendations. To avoid false-negative results caused by the presence of inhibitors, and to check for amplifiable DNA, the DNA samples were subjected to a conventional polymerase chain reaction (CPCR) to amplify the endogenous glyceraldehyde-3-phosphate dehydrogenase gene (gapdh) of mammals, following the established protocol (Birkenheuer et al., 2003). Internal control-PCR positive samples were subjected to $T$. vivax screening by means of loop-mediated isothermal amplification (LAMP) targeting the satellite repeat DNA.

\section{Molecular Detection of $T$. vivax}

The LAMP assay was carried out as described elsewhere (Njiru et al., 2011) using the following set of primers: outer primers: F3 (TGTTCTGGTGGCCTGTTGC) and B3 (GGCCGGAGCGAGAGGTGC); inner primers: FIP (GTGGAGCGTGCCAACGTGGCACCCGCTCCCAGACCATA) and BIP(TGTCTAGCGTGACGCGATGGAAGAGGGAGTGGGGAAGG); and loop primers: LF (CACATGGAGCATCAGGAC) and LB (CCGTGCACTGTCCCGCAC).

The LAMP reactions were performed in a reaction volume of $25 \mu \mathrm{L}$, consisting of the following: 5 pmol of the outer primers, $20 \mathrm{pmol}$ of the loop primers, $40 \mathrm{pmol}$ of the inner primers, $4 \mathrm{mM}$ of extra $\mathrm{MgSO}_{4^{\prime}} 1 \mathrm{M}$ betaine (SigmaAldrich, St. Louis, MO, USA) and $2.5 \mathrm{mM}$ of deoxynucleotide triphosphates mix (dNTP). The 1X ThermoPol reaction buffer (New England BioLabs, MA, USA) was used, containing $20 \mathrm{mM}$ of Tris- $\mathrm{HCl}(\mathrm{pH} 8.8), 10 \mathrm{mM}$ of KCl, $10 \mathrm{mM}$ of $\left(\mathrm{NH}_{4}\right)_{2} \mathrm{SO}_{4} 2 \mathrm{mM}$ of $\mathrm{MgSO}_{4}$ and $0.1 \%$ Triton X-100. The Bst DNA polymerase volume (large fragment; New England Biolabs) was $1 \mu \mathrm{L}$ (8 units). SYTO-9 fluorescence dye at $1.5 \mathrm{M}$ (Molecular Probes, OR, USA) and $2.5 \mu \mathrm{L}$ of each DNA sample were used as a template for each LAMP reaction (Njiru et al., 2011).

The reactions were conducted at $63^{\circ} \mathrm{C}$ for 60 minutes, using a QuantStudio 3 Thermal Cycler (Applied Biosystems). The reaction was stopped by increasing the temperature to $80^{\circ} \mathrm{C}$ for 5 mins. Melt curves were acquired using $0.5^{\circ} \mathrm{C}$ steps, with holds of $5 \mathrm{~s}$, from 63 to $96^{\circ} \mathrm{C}$. The results were assessed through observation of amplification curves using the QuantStudio 3 software. All the Cq (cycle thresholds) of each sample were annotated. Each LAMP assay was performed including duplicates of each goat tissue DNA sample. DNA of T. vivax (Cadioli et al., 2012) and ultrapure water were used as positive and non-template controls, respectively, in all LAMP assays.

\section{Results}

In general, throughout the experimental period, none of the animals showed any severe changes in physical examinations. However, some animals had apathy, pale mucous membranes and enlarged lymph nodes, but without pain on palpation.

Parasites were detected using the technique of Brener (1961) at six days after inoculation in all animals (Figure 1). Fluctuations in $T$. vivax parasitemia were observed during the trial period, with the highest peak observed at eight DAl for the animal C10 with $1.1 \times 10^{7}$ parasites $/ \mathrm{mL}$ of blood (Figure 1).

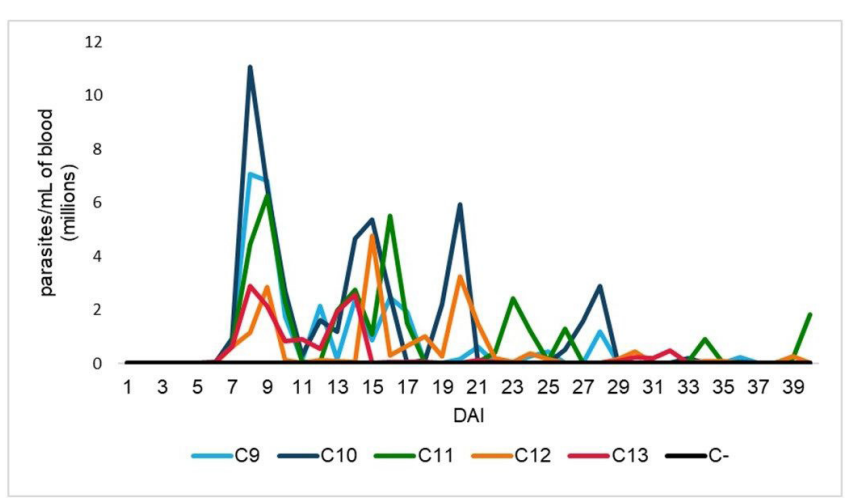

Figure 1. Mean T. vivax parasitemia recorded during the trial period. C9-C13: Infected goats. C-: Negative control. DAI: Days after inoculation. The animals were inoculated with $1.0 \times 10^{3}$ trypomastigote forms of $T$. vivax (Miranda isolate) intravenously. The parasite quantification was carried out using the thick-drop counting method as previously described (Brener, 1961). 
Histologically, a mononuclear inflammatory reaction characterized mainly by infiltration of lymphocytes, plasmocytes and perivascular and/or interstitial macrophages was observed in all the experimentally infected goats (Figure 2). Additionally, a hyperplastic reaction of the lymphoid tissues was observed, particularly in the spleen and peripheral lymph nodes, thus demonstrating a systemic reaction to persistent antigenic stimulation (Figure 2). In general, the endothelial cells of the tissues analyzed showed exacerbated reactivity, especially in the endothelium of venules and lymphatics system.
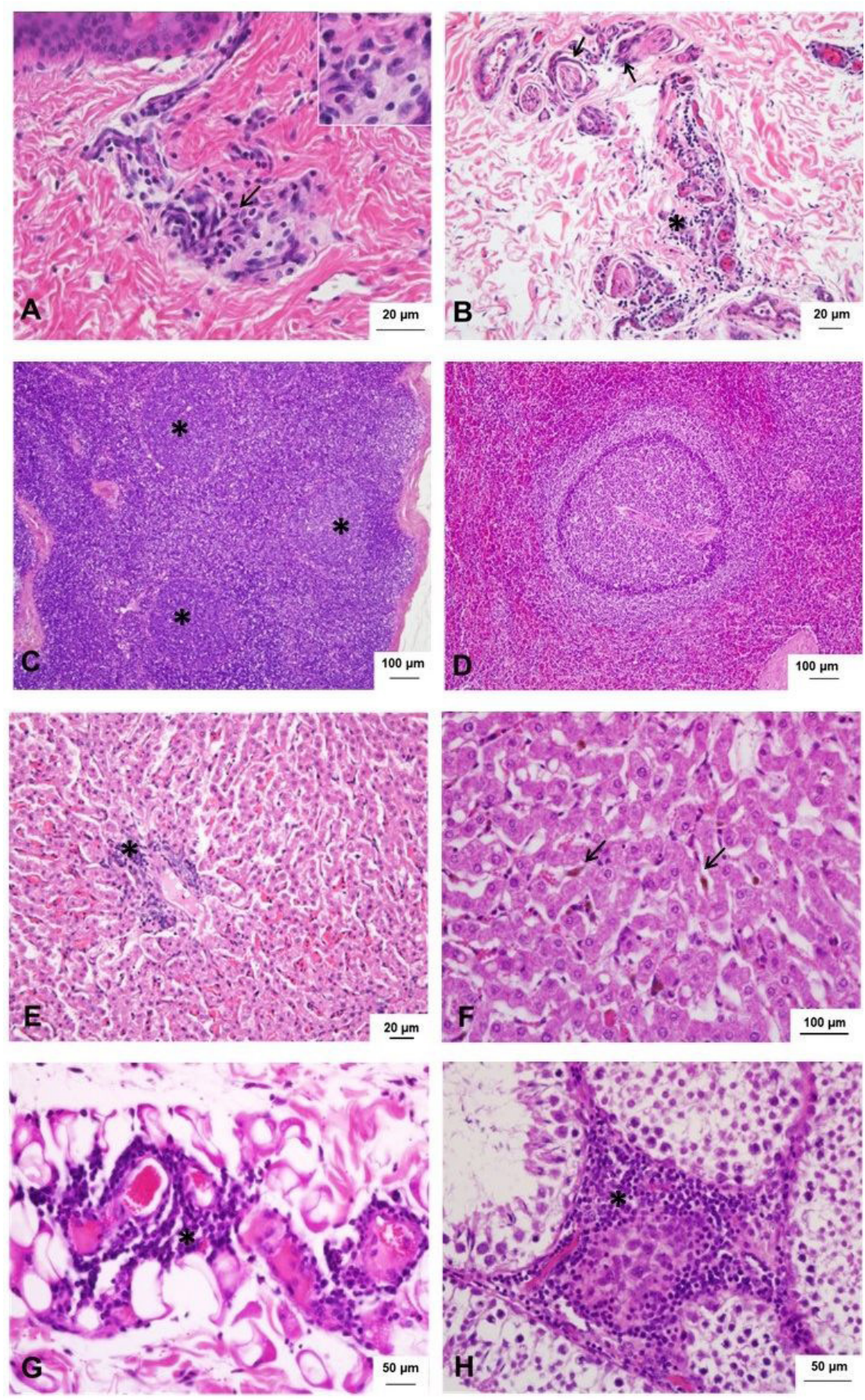

Figure 2. Histopathological study of goat infected with T. vivax. Skin - Perivascular mononuclear infiltrate (arrow) and eosinophilic perivascular infiltrate (inset) in the superficial dermis (A). Skin - Perivascular mononuclear infiltrate $\left({ }^{*}\right)$ and infiltrate around peripheral nerves (arrow) in the deep dermis (B). Lymph node - cortical and paracortical follicular (*) hyperplasia (C). Spleen hyperplasia of splenic lymphoid follicle (D). Liver - Discrete multifocal perivascular mononuclear infiltrate (E). Hemosiderosis in Kupffer cells (arrow) and vacuolization of hepatocytes (F). Hypodermis Perivascular mononuclear infiltrate in adipose tissue (G). Testicle - mononuclear infiltrate in the interstitium of the seminiferous tubules $(\mathrm{H})$. The tissue samples were collected in $40^{\text {th }}$ DAI. HE staining. 
Remarkably, all the samples obtained from the infected animals were positive for tissue-based IFA (Figure 3). None of the tissue samples from the negative control goat were positive for tissue-based IFA at 1:40 dilution (Figure 3).
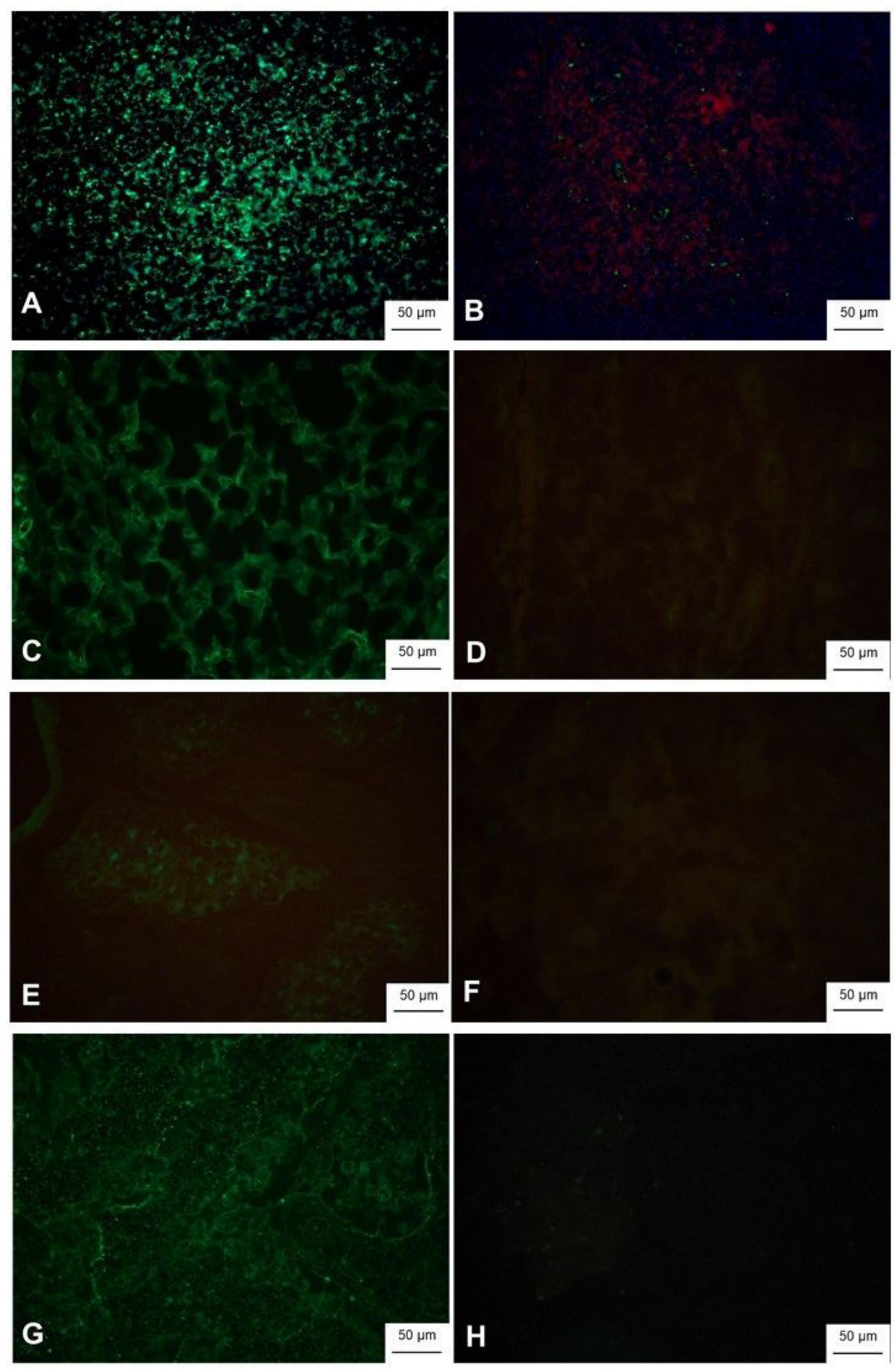

Figure 3. Tissue-based immunofluorescent assay for detection of T. vivax. Spleen - Positive (A) and negative (B) samples. Adipose tissue - Positive (C) and negative (D) samples. Skin - Positive (E) and negative (F) samples. Testicle - Positive (G) and negative (H) samples. Serum from T. vivax experimentally infected cattle diluted in PBS (1:40) was used as the primary antibody. Antibovine IgG (FITC conjugate) was used as the secondary antibody. Fluorescence (green) reveals the binding between FITC labeled secondary antibody and the antigen-antibody complex. Both primary and secondary antibodies were incubated at $37^{\circ} \mathrm{C}$ for 45 minutes and 30 minutes, respectively. 
All of the DNA samples extracted were positive in gapdh internal control PCR assays. All of the 35 goat tissue DNA samples from infected animals that were subjected to the LAMP assay were positive. The average melting temperature for the positive samples was $88.2^{\circ} \mathrm{C}(\mathrm{SD}=0.2)$. In addition, the average quantification cycle was $30.4(\mathrm{SD}=4.2)$. Likewise, analyzing only the adipose tissue DNA samples, the average melting temperature and quantification cycle were $88.0^{\circ} \mathrm{C}(S D=0.09)$ and $30.7(S D=3.6)$, respectively. All tissue DNA samples from the negative control animal were negative.

\section{Discussion}

In the present study, we report histopathological changes and the presence of $T$. vivax in different tissues, including in the adipose tissue of experimentally infected goats. To date, this is the first report of the occurrence of $T$. vivax in adipose tissue. Our results, together with the previously reported findings (Trindade et al., 2016), suggest the possibility that this site can be used by this protozoon during its life cycle.

Interestingly, although parasitemia was reported in all the experimentally infected goats, the clinical signs presented by the animals were mild. This finding was different from what had previously been reported (Batista et al., 2011). In that study, it was reported that goats infected with $T$. vivax $\left(1.25 \times 10^{5}\right.$ trypomastigotes $)$ isolated from a cow during an outbreak in the state of Paraíba, northeastern Brazil) presented marked mucosal pallor, apathy, fever and neurological disorders. These findings may have reflected the differences in virulence of the isolates used (Osório et al., 2008). In addition, the number of parasites used in the inoculums may have influenced the disparity of the results observed.

Generally, T. vivax is found in the circulatory system. However, during the course of infection, it has the ability to migrate to the tissues of its vertebrate hosts (Gardiner et al., 1989). In these sites, it plays an important role in the pathogenesis of inflammatory and degenerative lesions (Batista et al., 2011). The histopathological lesions seen in the present study were also observed in a previous study on experimentally $T$. vivax-infected goats (Batista et al., 2011). In addition, those authors described severe lesions in the central nervous system of the animals, including meningitis and meningoencephalitis.

Through using two different approaches (LAMP and IFA), we reported the presence of $T$. vivax in the adipose tissue of infected animals. Recently, Trindade et al. (2016) reported the presence of $T$. brucei in the adipose tissue of mice, which they suggested would be an important niche for the parasite. Furthermore, those authors demonstrated that this protozoon was metabolically active and that, from the fat, heart and brain, it was able to reestablish infection through colonizing the circulation (Trindade et al., 2016). Lastly, those same authors revealed metabolic differences between $T$. brucei obtained from the circulation (BSF) and those from adipose tissue (ATF). The ATF transcriptome included upregulated genes, including putative fatty acid $\beta$-oxidation enzymes. Furthermore, they reported that ATF could use fatty acids, i.e. myristate, and catabolize them via beta-oxidation, which could lead to production of ATP via the cycle of tricarboxylic acid and oxidative phosphorylation (Trindade et al., 2016).

Likewise, T. cruzi has been recorded in adipose tissue from mice and humans (Ferreira et al., 2011). In that study, the authors also reported that $T$. cruzi parasitized primary adipocytes in vitro and that both in humans and in mice, T. cruzi may persist in adipose tissue for a long time and become a reservoir of infection (Ferreira et al., 2011).

These findings raise some interesting points about the role of adipose tissue in the biology of $T$. vivax. Could the adipose tissue be a niche for T. vivax during its mammalian life cycle? Can T. vivax parasites use fatty acids as an external carbon source? Is it possible that the persistence of $T$. vivax in mammalian fat may contribute to treatment failures in animals?

Relapses of $T$. vivax infection after treatment with trypanocidal drugs such as diminazene diaceturate (DA) and isometamidium chloride (ISM) have been reported (Schönefeld et al., 1987; Cadioli et al., 2012; Bastos et al., 2017; Castilho et al., 2021). Despite some authors had suggested that $T$. vivax resistance to the drug is caused due to indiscriminate use, underdosing and formulations with inadequate chemotherapy concentrations (Schönefeld et al., 1987; Dagnachew \& Bezie, 2015; Tekle et al., 2018), it is also possible that the parasite is able to escape from trypanocide drugs by invading host tissues in which the drug does not reach levels high enough to eliminate it (Batista et al., 2011; Bastos et al., 2020; Castilho et al., 2021). In the latter scenario, after the half-life of the trypanocide drugs has expired, the parasites may leave their "refuge sites" and returns to the host's bloodstream.

In Brazil, DA and ISM are the only two trypanocide drugs licensed by the Ministry of Agriculture, Livestock and Supply (MAPA). They are generally used against T. vivax infection (Castilho et al., 2021). These drugs have half-lives of approximately 4.5 and 12 days, respectively (Eisler, 1996; Kaur et al., 2000). 
DA is widely used as a trypanocide among cattle, goats and sheep due to its activity against $T$. congolense and $T$. vivax, and it only has low toxic effects. It is a curative drug (Peregrine \& Mamman, 1993) and has higher concentrations in the liver and kidney (FAO, 1990). On the other hand, ISM accumulates in the liver, kidneys and spleen and at the inoculation site. From these sites, the drug is slowly released into the plasma and exerts prophylactic action (Kinabo \& Bogan, 1988). Thus, because of the short half-lives of these drugs, especially that of DA, the likelihood that these drugs might reach refuge sites for this parasite, e.g. skin and fat, at ideal concentrations for clearing parasites from these sites should be taken into account in cases of relapse of $T$. vivax infection.

Although we have presented robust results, given that blood of the animals was not removed before tissues collection, we can not rule out the possibility that tissue-based IFAs may reflect the parasites in the vasculature of the tissues rather than parasites that have crossed the endothelium and established in the extravascular spaces of tissues. In this way, future studies using perfused animals are much necessary to verify if $T$. vivax is able to cross the endothelium or if they are restricted to vascular systems.

In the current study, using serological and molecular approaches, we showed the presence of $T$. vivax in tissue samples from experimentally infected goats. Our findings, coupled with those of previous studies, show that adipose tissue and skin may be used as a refuge site for the parasite. These results shed some light on relapsed $T$. vivax cases after treatment with trypanocide drugs. Future studies aiming to assess whether these parasites from tissues are metabolically distinct from bloodstream forms, and how long the parasites can remain active in these sites and thereafter colonize the bloodstream, are necessary.

\section{References}

Almeida KS, Costa AF, Silva PC, Fagliari JJ, Machado RZ, Nascimento AAD. Acute phase proteins: a potential approach for diagnosing chronic infection by Trypanosoma vivax. Rev Bras Parasitol Vet 2012; 21(2): 97-100. http://dx.doi.org/10.1590/S198429612012000200005 . PMid:22832747.

Almeida KS, Freitas FLC, Tebaldi JH, Alessi AC, Machado RZ, Nascimento AA. Alterações clínicas, histopatológicas e enzimáticas em ovinos infectados experimentalmente por Trypanosoma vivax. Cienc Anim Bras 2010; 11(3): 669-676. http://dx.doi.org/10.5216/ cab.v11i3.5971

Bastos TSA, Faria AM, Cavalcante ASA, Madrid DMC, Zapa DMB, Nicaretta JE, et al. Comparison of therapeutic efficacy of different drugs against Trypanosoma vivax on experimentally infected cattle. Prev Vet Med 2020; 181: 105040. http://dx.doi.org/10.1016/j. prevetmed.2020.105040. PMid:32516747.

Bastos TSA, Faria AM, Madrid DMC, Bessa LCD, Linhares GFC, Fidelis OL Jr, et al. First outbreak and subsequent cases of Trypanosoma vivax in the state of Goiás, Brazil. Rev Bras Parasitol Vet 2017; 26(3): 366-371. http://dx.doi.org/10.1590/s198429612017019. PMid:28678894.

Batista JS, Riet-Correa F, Barbosa RC, Guerra JL. Infecção experimental por Trypanosoma vivax em ovinos. Pesq Vet Bras 2006; 26(1): 31-37. http://dx.doi.org/10.1590/S0100-736X2006000100007.

Batista JS, Riet-Correa F, Teixeira MMG, Madruga CR, Simões SVD, Maia TF. Trypanosomiasis by Trypanosoma vivax in cattle in the Brazilian semiarid: description of an outbreak and lesions in the nervous system. Vet Parasito/ 2007; 143(2): 174-181. http:// dx.doi.org/10.1016/j.vetpar.2006.08.017. PMid:16965857.

Batista JS, Rodrigues CM, García HA, Bezerra FS, Olinda RG, Teixeira MMG, et al. Association of Trypanosoma vivax in extracellular sites with central nervous system lesions and changes in cerebrospinal fluid in experimentally infected goats. Vet Res 2011; 42(1): 63. http://dx.doi.org/10.1186/1297-9716-42-63. PMid:21569364.

Birkenheuer AJ, Levy MG, Breitschwerdt EB. Development and evaluation of a seminested PCR for detection and differentiation of Babesia gibsoni (Asian genotype) and B. canis DNA in canine blood samples. J Clin Microbiol 2003; 41(9): 4172-4177. http:// dx.doi.org/10.1128/JCM.41.9.4172-4177.2003. PMid:12958243.

Brener Z. Contribuição ao estudo da terapêutica experimental da doença de Chagas [Tese Livre-Docência]. Belo Horizonte: Universidade Federal de Minas Gerais; 1961.

Cadioli FA, Barnabé PA, Machado RZ, Teixeira MCA, André MR, Sampaio PH, et al. First report of Trypanosoma vivax outbreak in dairy cattle in São Paulo state, Brazil. Rev Bras Parasito/ Vet 2012; 21(2): 118-124. http://dx.doi.org/10.1590/S1984-29612012000200009. PMid:22832751.

Capewell P, Cren-Travaillé C, Marchesi F, Johnston P, Clucas C, Benson RA, et al. The skin is a significant but overlooked anatomical reservoir for vector-borne African trypanosomes. eLife 2016; 5: e17716. http://dx.doi.org/10.7554/eLife.17716. PMid:27653219. 
Castilho KJGA No, Garcia ABCF, Fidelis OLJr, Nagata WB, André MR, Teixeira MMG, et al. Follow-up of dairy cattle naturally infected by Trypanosoma vivax after treatment with isometamidium chloride. Rev Bras Parasitol Vet 2021; 30(1): e020220. http://dx.doi. org/10.1590/s1984-29612021019. PMid:33909833.

Cortez AP, Rodrigues AC, Garcia HA, Neves L, Batista JS, Bengaly Z, et al. Cathepsin L-like genes of Trypanosoma vivax from Africa and South America - characterization, relationships and diagnostic implications. Mol Cell Probes 2009; 23(1): 44-51. http://dx.doi. org/10.1016/j.mcp.2008.11.003. PMid:19063960.

D'Archivio S, Cosson A, Medina M, Lang T, Minoprio P, Goyard S. Non-invasive in vivo study of the Trypanosoma vivax infectious process consolidates the brain commitment in late infections. PLoS Neg/ Trop Dis 2013; 7(1): e1976. http://dx.doi.org/10.1371/ journal.pntd.0001976. PMid:23301112.

Dagnachew S, Bezie M. Review on Trypanosoma vivax. Afr J Basic App/ Sci 2015; 7(1): 41-64.

Dávila AMR, Silva RAMS. Animal trypanosomiasis in South America: current status, partnership, and information technology. Ann N Y Acad Sci 2000; 916(1): 199-212. http://dx.doi.org/10.1111/j.1749-6632.2000.tb05291.x. PMid:11193622.

Eisler MC. Pharmacokinetics of the chemoprophylactic and chemotherapeutic trypanocidal drug isometamidium chloride (Samorin) in cattle. Drug Metab Dispos 1996; 24(12): 1355-1361. PMid:8971142.

FAO - Food and Agriculture Organization of the United Nations. Residues of some veterinary drugs in animals and foods. Rome: Food and Agriculture Organization of the United Nations - FAO; 1990

Ferreira AVM, Segatto M, Menezes Z, Macedo AM, Gelape C, Andrade LO, et al. Evidence for Trypanosoma cruzi in adipose tissue in human chronic Chagas disease. Microbes Infect 2011; 13(12-13): 1002-1005. http://dx.doi.org/10.1016/j.micinf.2011.06.002. PMid:21726660.

Fidelis OL Jr, Sampaio PH, Machado RZ, André MR, Marques LC, Cadioli FA. Evaluation of clinical signs, parasitemia, hematologic and biochemical changes in cattle experimentally infected with Trypanosoma vivax. Rev Bras Parasitol Vet 2016; 25(1): 69-81. http://dx.doi.org/10.1590/S1984-29612016013. PMid:27007249.

Gardiner PR, Assoku RKG, Whitelaw DD, Murray M. Haemorrhagic lesions resulting from Trypanosoma vivax infection in ayrshire cattle. Vet Parasitol 1989; 31(3-4): 187-197. http://dx.doi.org/10.1016/0304-4017(89)90069-1. PMid:2763442.

Giordani F, Morrison LJ, Rowan TG, Koning HP, Barrett MP. The animal trypanosomiases and their chemotherapy: a review. Parasitology 2016; 143(14): 1862-1889. http://dx.doi.org/10.1017/S0031182016001268. PMid:27719692.

Hoare CA. The trypanosomes of mammals. Oxford: Blackwell Scientific Publications; 1972.

Jones TW, Dávila AMR. Trypanosoma vivax - out of Africa. Trends Parasito/ 2001; 17(2): 99-101. http://dx.doi.org/10.1016/S14714922(00)01777-3. PMid:11228017.

Kaur G, Chaudhary RK, Srivastava AK. Pharmacokinetics, urinary excretion and dosage regimen of diminazene in crossbred calves. Acta Vet Hung 2000; 48(2): 187-192. PMid:11402701.

Kinabo LDB, Bogan TLJ. The pharmacology of isometamidium. J Vet Pharmacol Ther 1988; 11(3): 233-245. http://dx.doi. org/10.1111/j.1365-2885.1988.tb00148.x. PMid:3054150.

Machado RZ, Montassier HJ, Pinto AA, Lemos EG, Machado MRF, Valadão IFF, et al. An enzyme-linked immunosorbent assay (ELISA) for the detection of antibodies against Babesia bovis in cattle. Vet Parasito/ 1997; 71(1): 17-26. http://dx.doi.org/10.1016/ S0304-4017(97)00003-4. PMid:9231985.

Nantulya VM. Trypanosomiasis in domestic animals: the problems of diagnosis. Rev Sci Tech 1990; 9(2): 357-367. http://dx.doi. org/10.20506/rst.9.2.507. PMid:2132685.

Njiru ZK, Ouma JO, Bateta R, Njeru SE, Ndungu K, Gitonga PK, et al. Loop-mediated isothermal amplification test for Trypanosoma vivax based on satellite repeat DNA. Vet Parasitol 2011; 180(3-4): 358-362. http://dx.doi.org/10.1016/j.vetpar.2011.03.021. PMid:21482026.

Osório ALAR, Madruga CR, Desquesnes M, Soares CO, Ribeiro LRR, Costa SCG. Trypanosoma (Duttonella) vivax: its biology, epidemiology, pathogenesis, and introduction in the New World - a review. Mem Inst Oswaldo Cruz 2008; 103(1): 1-13. http:// dx.doi.org/10.1590/S0074-02762008000100001. PMid:18368231.

Peregrine AS, Mamman M. Pharmacology of diminazene: a review. Acta Trop 1993; 54(3-4): 185-203. http://dx.doi.org/10.1016/0001706X(93)90092-P. PMid:7902657.

Rebeski DE, Winger EM, Van Rooij EMA, Schöchl R, Schuller W, Dwinger RH, et al. Pitfalls in the application of enzyme-linked immunoassays for the detection of circulating trypanosomal antigens in serum samples. Parasitol Res 1999; 85: 550-556. http:// dx.doi.org/10.1007/s004360050594. PMid:10382604. 
Sampaio PH, Fidelis OLJr, Marques LC, Machado RZ, Barnabé PA, André MR, et al. Acute-phase protein behavior in dairy cattle herd naturally infected with Trypanosoma vivax. Vet Parasitol 2015; 211(3-4): 141-145. http://dx.doi.org/10.1016/j.vetpar.2015.05.014. PMid:26012859.

Schönefeld A, Röttcher D, Moloo SK. The sensitivity to trypanocidal drugs of Trypanosoma vivax isolated in Kenya and Somalia. Trop Med Parasitol 1987; 38(3): 177-180. PMid:3432953.

Seidl A, Dávila AMR, Silva RAMS. Estimated financial impact of Trypanosoma vivax on the Brazilian Pantanal and Bolivian lowlands. Mem Inst Oswaldo Cruz 1999; 94(2): 269-272. http://dx.doi.org/10.1590/S0074-02761999000200027. PMid:10224541.

Serra-Freire NM, Rezende AML. Stomoxys calcitrans, um vetor mecânico do Trypanosoma vivax no Brasil e notas sobre o comportamento do parasito no vetor. Arq Univ Fed Rural Rio de Janeiro 1988; 11: 77-82.

Silva RAMS, Silva JA, Schneider RC, Freitas J, Mesquita DP, Mesquita TC, et al. Outbreak of trypanosomiasis due to Trypanosoma vivax (Ziemann, 1905) in bovines of the Pantanal, Brazil. Mem Inst Oswaldo Cruz 1996; 91(5): 561-562. http://dx.doi.org/10.1590/ S0074-02761996000500005. PMid:9137742.

Silva TMF, Olinda RG, Rodrigues CMF, Câmara ACL, Lopes FC, Coelho WAC, et al. Pathogenesis of reproductive failure induced by Trypanosoma vivax in experimentally infected pregnant ewes. Vet Res 2013; 44(1): 1. http://dx.doi.org/10.1186/1297-971644-1. PMid:23289625.

Stijlemans B, Vankrunkelsven A, Caljon G, Bockstal V, Guilliams M, Bosschaerts T, et al. The central role of macrophages in trypanosomiasis-associated anemia: rationale for therapeutical approaches. Endocr Metab Immune Disord Drug Targets 2010; 10(1): 71-82. http://dx.doi.org/10.2174/187153010790827966. PMid:20158497.

Tekle T, Terefe G, Cherenet T, Ashenafi H, Akoda KG, Teko-Agbo A, et al. Aberrant use and poor quality of trypanocides: a risk for drug resistance in south western Ethiopia. BMC Vet Res 2018; 14(1): 4. http://dx.doi.org/10.1186/s12917-017-1327-6. PMid:29304792.

Trindade S, Rijo-Ferreira F, Carvalho T, Pinto-Neves D, Guegan F, Aresta-Branco F, et al. Trypanosoma brucei parasites occupy and functionally adapt to the adipose tissue in mice. Cell Host Microbe 2016; 19(6): 837-848. http://dx.doi.org/10.1016/j. chom.2016.05.002. PMid:27237364.

Waal T. Advances in diagnosis of protozoan diseases. Vet Parasitol 2012; 189(1): 65-74. http://dx.doi.org/10.1016/j. vetpar.2012.03.033. PMid:22503386.

Whitelaw DD, Gardiner PR, Murray M. Extravascular foci of Trypanosoma vivax in goats: the central nervous system and aqueous humor of the eye as potential sources of relapse infections after chemotherapy. Parasitology 1988; 97(1): 51-61. http://dx.doi. org/10.1017/S0031182000066737. PMid:3174238. 